\title{
Soil Seed Banks of Tree Species from Natural Forests, Restoration Sites, and Abandoned Areas in Chiang Mai, Thailand
}

\author{
Patsavipich Rungrojtrakool ${ }^{1}$, Pimonrat Tiansawat ${ }^{2,3}$, Arunothai Jampeetong ${ }^{3}$, Dia Panitnard \\ Shannon ${ }^{3}$ and Sutthathorn Chairuangsri ${ }^{2,3, *}$ \\ 1 PhD Degree Program in Environmental Science, Environmental Science Research Center, Faculty of \\ Science, Chiang Mai University, Chiang Mai, 50200, Thailand; email: kiku8i8@gmail.com \\ 2 Environmental Science Research Center, Faculty of Science, Chiang Mai University, Chiang Mai, 50200, \\ Thailand \\ 3 Department of Biology, Faculty of Science, Chiang Mai University, Chiang Mai, 50200, Thailand \\ * Correspondence author: s.suwann@gmail.com
}

\begin{abstract}
Soil seed banks have been used for investigation of natural regeneration of forests. In this study, we compared seed density and species composition of soil seed banks of trees among natural forests, restored forests of different ages, and abandoned agricultural land. The soil seed banks were collected from a natural forest (NF), 12-year-old and 17-year-old restoration sites (RF12y and RF17y), and 17-year-old abandoned site (AA) at Ban Mae Sa Mai, Chiang Mai, Thailand. A seedling emergence technique was used to assess seed density and species of emerged seedlings was identified. We found 5-8 tree species at each site. Seed densities in the study areas ranged from 43 to 298 seeds $/ \mathrm{m}^{2}$. The seed density of RF12y was significantly higher than that of both NF and AA but not significantly different than RF17y $(p<0.01)$. Although there was no significant relationship between the restoration ages and the seed densities of the soil seed banks, the species composition of standing vegetation was related to the seed bank species. Sorensen's similarities between the species composition of the soil seed banks and the existing trees in each area were between 0 and $13.79 \%$, suggesting seed dispersal of both within and across study sites. Eight out of fourteen species in the soil seed banks were dispersed into restoration sites without standing vegetation of those species. Seven of those were animal-dispersed species. The selected native trees, framework species, attracted small seed dispersers into the study areas, especially at the restoration sites. This finding suggests that active forest restoration improved natural regeneration in restoration sites as well as neighboring areas via seed dispersal.
\end{abstract}

Keywords: forest restoration; framework species; tropical dry forest; northern Thailand; restoration ages; restored forests; soil seed banks; standing vegetation

\section{Introduction}

A soil seed bank consists of viable seeds resting in litters and soils (González-Rivas et al., 2009). Soil seed banks are often studied as part of investigations into natural regeneration of disturbed areas as well as abandoned sites (Chen et al., 2013; González-Rivas et al., 2009; Kostel-Hughes et al., 1998; Martins and Engel, 2007). Moreover, previous studies have investigated the differences in soil seed bank composition among seasons and microhabitats (dos Santos et al., 2013; Li et al., 2007). Seed density and species richness are important factors for understanding soil seed banks (dos Santos et al., 2013; González-Rivas et al., 2009; Kostel-Hughes et al., 1998;). Species richness represents the diversity of seeds deposited in the soil, while seed density is defined as the number of seeds per unit area. Seed density in soil seed banks may reflect the amount of seed rain to the area from the dispersal of seeds of standing vegetation and/or of nearby vegetation. The composition and density of soil seed banks differ among forest types, and the successional stage of the area. In highly disturbed land, species in the soil seed bank consists of herbs and grasses. Seeds of primary trees are rarely found in soil seed banks of old forests because their characteristics are large size, high water content, and rapid germination (Garwood, 1989; Vázquez-Yanes and OrozcoSegovia, 1996). Moreover, the amount of seeds of grasses and herbs contained in young forests had 
higher seed density than those found in the older forests, even though the proportion of woody species seeds became greater in the old ones (Cao et al., 2000).

One of the forest restoration approaches used to restore forest areas in Thailand is called the 'framework species method'. This method was first developed in Queensland, Australia and initially established in Chiang Mai in 1998. The oldest restored forest with this method was planted in 1998 in Ban Mae Sa Mai, Chiang Mai province (Blakesley et al., 2002). The main concepts of this method are planting 20-30 native tree species comprising both pioneer and climax species to enhance the reestablishment of a forest community. The characteristics of selected species include the following features: fast-growing seedlings, high survival rate in degraded areas, dense and wide crown spread to compete against weeds, promoting seed dispersal by attracting wildlife, resilience to fire, and easily propagating in a nursery (Elliott et al., 2003).

There were previous studies that used soil seed banks along with physical factors to determine natural regeneration in both disturbed and abandoned areas; however, few studies focused on soil seed banks in restored forests (González-Rivas et al., 2009; Miao et al., 2016). This research study aimed to determine soil seed bank dynamics among restoration periods in the areas restored with the framework species method. The seed banks in restored sites were compared with the nearest natural forest and the abandoned areas to answer two questions: how do forest restoration ages affect seed deposition in soils? and how does the framework species method affect species composition in the soil seed banks? Previous literature reviews predicted that seed densities of tree species in the older restored plots would be greater than the young plots, excluding the seeds of grasses and herbs. The framework species method has the potential to influence seed dispersal by animal (Elliott et al., 2003). We postulated that the major proportion of species compositions in the soil seed banks will be animal-dispersed species as well as those similar to standing vegetation from adjacent areas.

\section{Methods}

\subsection{Study area}

The study area is located in Ban Mae Sa Mai village which belongs to Doi Suthep-Pui National Park in Mae Rim District, Chiang Mai province, northern Thailand. During the 1960s, the surrounding seasonal tropical dry forest had been trespassed for local usage and agricultural purposes. Around the 1980s, the villagers had not only protected their forest areas according to their spiritual beliefs but also established a community conservation association. Therefore, Dong Seng, the secondary natural forest has been protected for at least 30 years before this study was undertaken. The forest restoration sites in this study were planted using the "framework species method" in 1998 and 2003, while the abandoned areas were left for natural regeneration since 1998. In 1998, 28 tree species were planted while in 2003, 36 species were planted. Both the restored and abandoned areas were protected from forest fires. At the beginning of the restoration program 3,125 seedlings/ha of framework tree species were planted in the restored areas. The study area is located in the Mae Sa valley $18^{\circ} 51^{\prime} \mathrm{N}$ to $18^{\circ} 52^{\prime} \mathrm{N}$ latitude and $98^{\circ} 50^{\prime} \mathrm{E}$ to $98^{\circ} 51^{\prime} \mathrm{E}$ longitude at approximately $1,200-1,400$ $\mathrm{m}$ elevation (Table 1, Figure 1). General information and the description of the study sites were demonstrated in Table 1. Average annual rainfall in 1998-2018 at the National Park headquarters and Bhubing Palace were 1,540.2 $\mathrm{mm}$ and $1609 \mathrm{~mm}$, respectively. The average monthly rainfall of both sites during 1998-2018 are shown in Figure 2 (Upper Northern Region Irrigation Hydrology Center, 2020). These sites are situated in the same national park at $1,050 \mathrm{~m}$ and 1,375 $\mathrm{m}$ above sea level, respectively (Maxwell and Elliott, 2001). Annual rainfall in 2015 at Mae Sa Mai meteorological station was $1,033.88 \mathrm{~mm}$. Ambient temperature was between $13-29{ }^{\circ} \mathrm{C}$ within the same year (Royal Project Thailand (Mae Sa Mai Station), 2016). Six months of the wet season begin from May to October, while the remaining months are the dry season. This forest is defined as a seasonal tropical dry forest as mentioned in Blakesley et al. (2002). 
Table 1. General information of four study sites (RF12y $=12$-year-old restored forest, RF17y $=17$ year-old restored forest, $\mathrm{NF}=$ natural forest, $\mathrm{AA}=$ abandoned area).

\begin{tabular}{|c|c|c|c|c|}
\hline Study site & RF12y & RF17y & NF & AA \\
\hline Treatment & $\begin{array}{l}\text { restored with } \\
\text { framework species } \\
\text { method since } 2003\end{array}$ & $\begin{array}{l}\text { restored with } \\
\text { framework species } \\
\text { method since } 1998\end{array}$ & $\begin{array}{l}\text { a local conservation area } \\
\text { (a sacred forest) }\end{array}$ & $\begin{array}{c}\text { abandoned areas since } \\
1998\end{array}$ \\
\hline Description & $\begin{array}{l}\text { abandoned agricultural } \\
\text { areas, with some } \\
\text { planted exotic species }\end{array}$ & $\begin{array}{l}\text { previous agricultural } \\
\text { areas ( } 3.2 \text { hectares) }\end{array}$ & $\begin{array}{c}\text { a secondary disturbed } \\
\text { forest conserved over } 30 \\
\text { years }\end{array}$ & $\begin{array}{l}\text { previous agricultural } \\
\text { areas connecting to } \\
\text { RF17y }\end{array}$ \\
\hline Altitude (m) & $1314.3 \pm 8.4$ & $1330.7 \pm 1.5$ & $1208.1 \pm 17.7$ & $1325.5 \pm 1.3$ \\
\hline Age (year) & 12 & 17 & $>30$ & 17 \\
\hline Dominance species & $\begin{array}{l}\text { Artocarpus lakoocha } \\
\text { Buch.-Ham., } \\
\text { Beilschmiedia } \\
\text { intermedia C.K. Allen, } \\
\text { Eucalyptus sp., Litsea } \\
\text { glutinosa (Lour.) C.B. } \\
\text { Rob., Prunus } \\
\text { cerasoides Buch.-Ham. } \\
\text { ex D. Don, } \\
\text { Sarcosperma arboreum } \\
\text { Hook.f. }\end{array}$ & $\begin{array}{c}\text { Castanopsis diversifolia } \\
\text { ( Kurz) King ex Hook.f., } \\
\text { Choerospondias } \\
\text { axillaris (Roxb.) } \\
\text { B.L.Burtt and A.W.Hill, } \\
\text { Dalbergia ovata } \\
\text { Benth., Machilus } \\
\text { gamblei King ex J. D. } \\
\text { Hooker }\end{array}$ & $\begin{array}{l}\text { Machilus gamblei King } \\
\text { ex Hook. f., Ocotea } \\
\text { lancifolia (Schott) } \\
\text { Mez,Schima wallichii } \\
\text { Choisy, Wendlandia } \\
\text { tinctoria (Roxb.) DC. }\end{array}$ & $\begin{array}{l}\text { Artocarpus lacucha } \\
\text { Buch.-Ham., Litsea } \\
\text { cubeba (Lour.) } \\
\text { Pers.,Prunus cerasoides } \\
\text { Buch.-Ham. ex D. Don, } \\
\text { Schima wallichii Choisy, } \\
\text { Toxicodendron } \\
\text { rhetsoides (W. G. Craib) } \\
\text { Tardieu }\end{array}$ \\
\hline
\end{tabular}

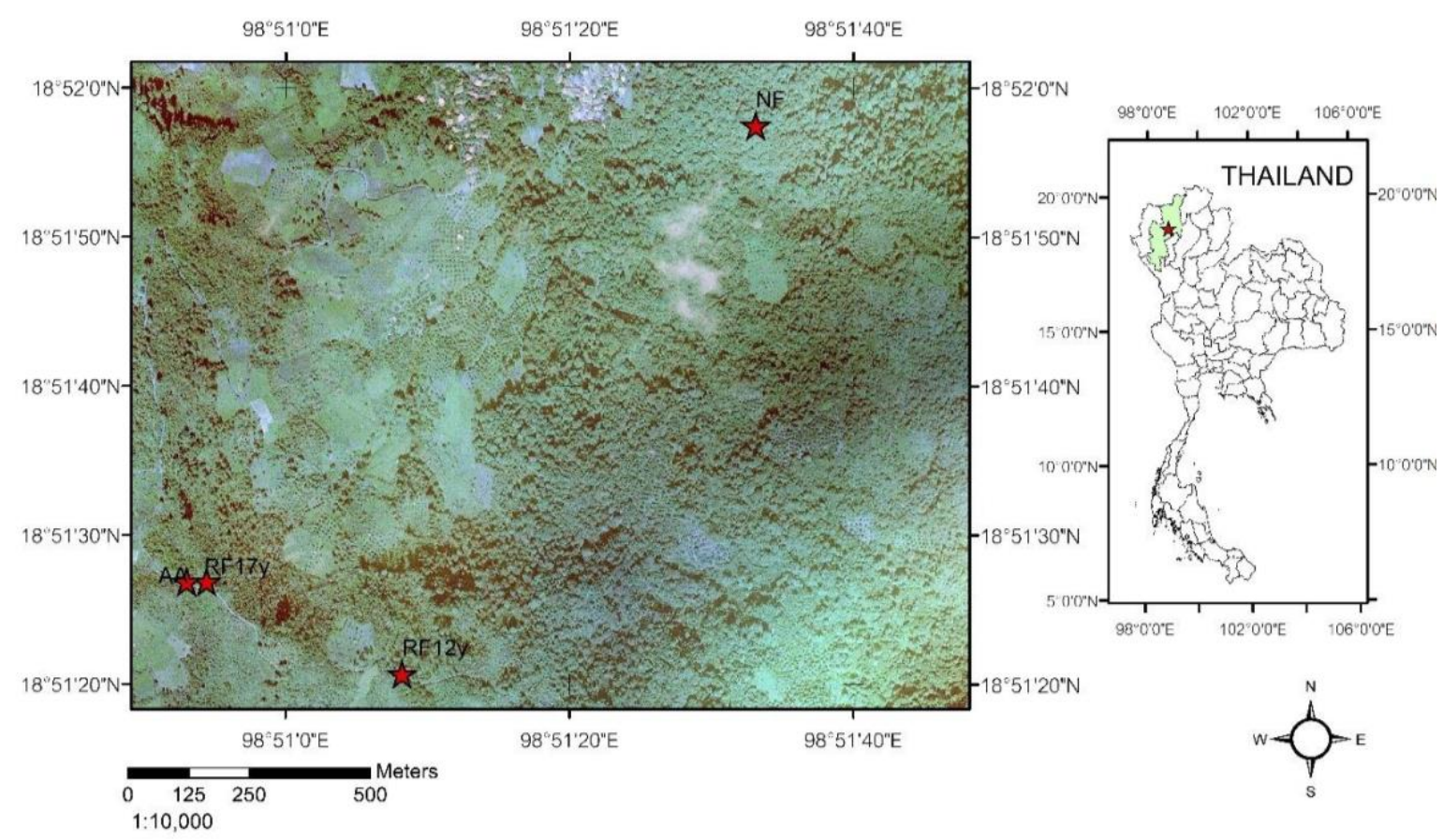

Figure 1. Study sites in Ban Mae Sa Mai, Mae Rim District, Chiang Mai, Thailand are indicated by dark color with a star (right), and the aerial photograph was captured in 2002 (left), $(\mathrm{RF} 12 \mathrm{y}=12$-year-old restored forest, $\mathrm{RF} 17 \mathrm{y}=17$-year-old restored forest, NF = natural forest, $A A=$ abandoned area). 


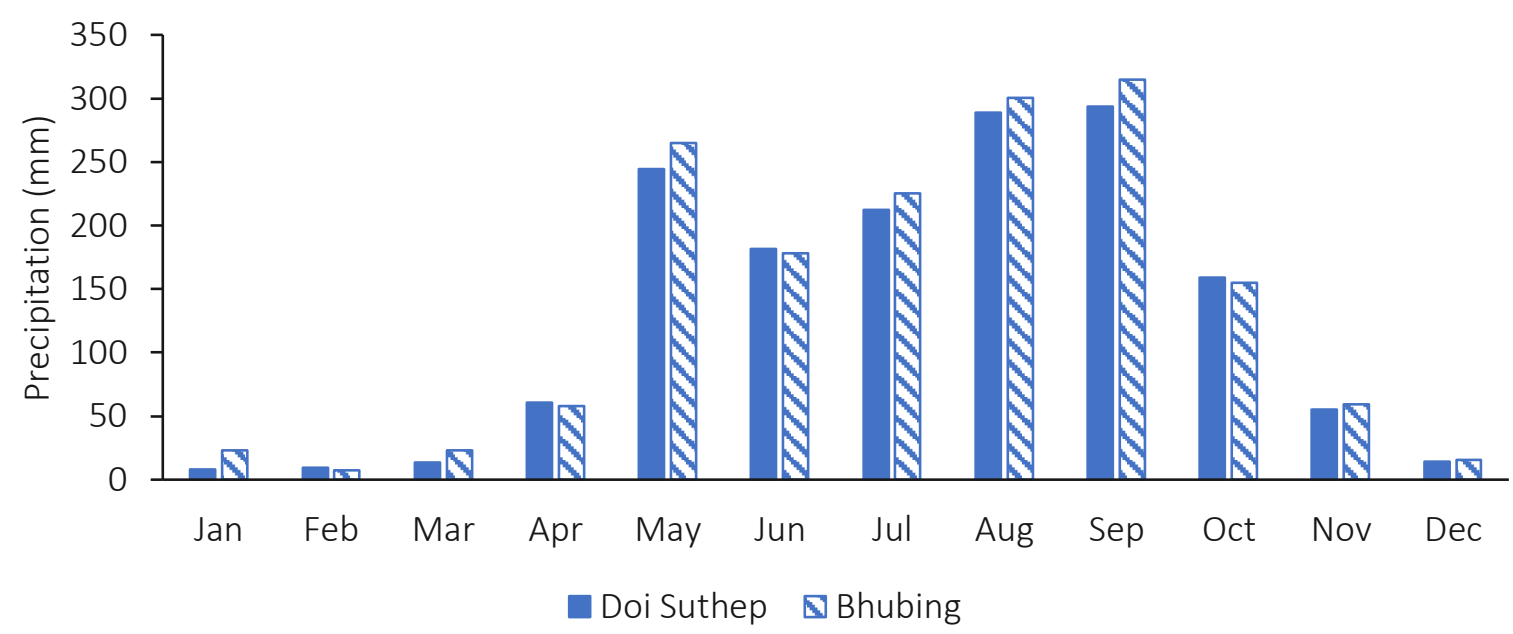

Figure 2. Average monthly precipitation $(\mathrm{mm})$ at Doi Suthep-Pui National Park and Bhubing Palace, Chiang Mai, Thailand: 1998-2018.

\subsection{Tree survey}

There were four study sites: natural forest (NF), 12-year-old and 17-year-old restoration sites (RF12y and RF17y), and 17-year-old abandoned site (AA). In each study site, three $20 \times 20 \mathrm{~m}$ permanent plots were established. Mature trees in the permanent plots were surveyed. All the mature trees with a diameter at breast height $(\mathrm{dbh})$ at least at $2.5 \mathrm{~cm}$ were identified, marked, counted, and recorded. The indices included number of trees, species richness $\left(\mathrm{N}_{0}\right)$, Shannon's diversity index $\left(H^{\prime}\right)$, maximum diversity $\left(H_{\max }\right)$, and evenness (E) (Ludwig and Reynolds, 1988). The indices were calculated according to the following formulas (1)-(3):

$$
\begin{aligned}
& H^{\prime}=-\sum_{i=1}^{S} p_{i} \ln p_{i} \\
& H_{\max }=\ln N \\
& E=\frac{H^{\prime}}{H_{\max }}
\end{aligned}
$$

Where: $\quad S=$ total number of species

$\mathrm{N}=$ total number of individuals

$i=1,2,3, \ldots, S$

$\mathrm{n}_{\mathrm{i}}=$ number of individuals of $\mathrm{i}^{\text {th }}$ species

$p_{i}=n_{i} / N$, proportional abundance of $i^{\text {th }}$ species.

Tree densities of each study site were estimated from a total number of the mature trees found in $1,200 \mathrm{~m}^{2}$ ( 3 plots) and calculated back to trees/ha.

\subsection{Soil seed bank collection}

The stratified sampling method of Kostel-Hughe et al. (1998) was used to collect soil samples. In the same permanent plots for tree survey, four $10 \times 10-\mathrm{m}$ subplots were established. For each subplot, 10 locations of soil samples were collected. At each location, cylinder soil core of $5-\mathrm{cm}$ diameter and 5-cm depth was used to collect the soil sample. The ten soil samples from each subplot were mixed together to be a replicate. There were twelve replicates for each study site. To calculate yearly seed density, the soil samples were collected twice, in June 2015 and March 2016.

To investigate seed density and species composition of the soil seed banks, the soil samples were handled using a process based on Kostel-Hughe et al. (1998). The soil samples were placed in 
plastic bags and kept in dark and cold conditions for no longer than four weeks before sowing. To remove tree branches and leaf litters, the soil samples from each subplot were sieved through the $0.5-\mathrm{cm}$ mesh. The bigger seeds, left on the mesh were included in the samples. The sieved soils were spread on plastic trays bedded with $1 \mathrm{~cm}$ of sterile soil for approximately $2-3 \mathrm{~cm}$ in total depth. To control seed contamination in the experiment, control trays containing 2-3 cm of sterile soil were randomly placed among the treatments. The soil samples were germinated under nursery conditions: partial shade with transparent roofs and sufficient watering. Only tree seeds that grew to become small seedlings, providing a leaf and a root within 12 weeks, were counted as belonging to soil seed banks. Those tree seedlings were identified using the Vegetation and Vascular Flora of Doi Suthep-Pui National Park (Maxwell and Elliott, 2001), and FORRU database (Forest Restoration Research Unit, Chiang Mai University (FORRU-CMU), 2014).

\subsection{Data analysis}

\subsubsection{Soil seed banks variation among study sites}

R software version 3.3.1 was used for statistical analyses (R Core Team, 2016). The KruskalWallis test, as implemented by the kruskal.test function in $R$, was used to compare the seed densities among sites and times. A post hoc test, the Nemenyi test, as implemented in the PMCMR package, was performed after the Kruskal-Wallis test to compare among sites (Pohlert, 2014).

\subsubsection{Species similarity of soil seed banks and mature trees}

The richness and diversity of tree species found in the soil samples were compared to the existing mature trees. Sorensen's index was calculated to examine the similarity between the tree species found in the soil seed banks and the mature trees (Sorensen, 1948). The Sorensen's similarity was calculated as shown in equation (4):

$$
\text { Sorensen's similarity }=\frac{2 c}{a+b} \times 100
$$

Where: $a=$ the number of species in a population

$b=$ the number of species in the other population

$\mathrm{c}=$ the number of species found in both populations.

\subsubsection{Proportion of planted tree species in the soil seed banks}

The species composition in the soil seed banks were compared with that of standing vegetation from the current tree survey. The numbers of planted and non-planted tree species were plotted in a graph to verify the proportion of seed dispersal from the planted species and to observe a potential of animal dispersal of non-planted species.

\section{Results and Discussion}

\subsection{Tree community}

The numbers of trees in natural forest (NF) and 17-year-old restored forest (RF17y) were two and three times larger than 12-year-old restored forest (RF12y) and abandoned area (AA), respectively (Table 2). Species richness $\left(N_{0}\right)$ of RF17y was close to NF. The species richness of both sites was slightly larger than RF12y and AA. Shannon index $\left(H^{\prime}\right)$ ranged from 2.91 to 3.44 , and $H_{\max }$ ranged from 3.71 to 4.80 . Species evenness (E) ranged from 0.64 in NF to 0.78 in AA. Tree density in each study site ranged from 342 trees/ha in the abandoned area to 1,008 trees/ha in the 17-yearold old restoration site. The tree density of NF (975 trees/ha) was close to that found in the RF17y. Although RF12y had low tree density at 542 trees/ha, the tree density was higher than that of the abandoned area. 
Table 2. Number of trees, species richness $\left(\mathrm{N}_{0}\right)$, Shannon's diversity index $\left(\mathrm{H}^{\prime}\right)$, maximum diversity $\left(H_{\max }\right)$, and evenness $(E)$ of mother trees in the study sites (RF12y $=12$-year-old restored forest, RF17y $=17$-year-old restored forest, $\mathrm{NF}=$ natural forest, $\mathrm{AA}=$ abandoned area).

\begin{tabular}{lllll}
\hline & \multicolumn{3}{c}{ Site } \\
\cline { 2 - 5 } Diversity index & RF12y & RF17y & NF & AA \\
\hline Number of trees & 65 & 121 & 117 & 41 \\
$\mathrm{~N}_{0}$ & 30 & 40 & 38 & 22 \\
$\mathrm{H}^{\prime}$ & 3.16 & 3.44 & 3.03 & 2.91 \\
$\mathrm{H}_{\max }$ & 4.17 & 4.80 & 4.76 & 3.71 \\
$\mathrm{E}$ & 0.76 & 0.72 & 0.64 & 0.78 \\
\hline
\end{tabular}

\subsection{Soil seed banks}

Mean seed densities of tree species per year varied between $40-300$ seeds $/ \mathrm{m}^{2}$ among 4 study sites (Table 3). The highest seed density belonged to the 12-year-old restoration site (RF12y, 298 seeds $/ \mathrm{m}^{2}$ ) while the lowest seed density was found in both natural forest (NF) and abandoned area (AA) (43 seeds $/ \mathrm{m}^{2}$ ) (Table 3 ). The mean seed densities were significantly different among the study sites $\left(\chi^{2}=16.346, d f=3, p=0.0096\right)$. The seed density of RF12y was significantly greater than both of NF and AA $(p<0.01)$. The 12 -year-old restoration site had approximately 4-6 times larger seed density than the other study sites.

Table 3. Seed densities of the soil seed banks $(n=12)$ from four study sites (RF12y $=12$-year-old restored forest, $\mathrm{RF} 17 \mathrm{y}=17$-year-old restored forest, $\mathrm{NF}=$ natural forest, $\mathrm{AA}=$ abandoned area).

\begin{tabular}{cc}
\hline Study site & Seed density \pm SD* (seeds/m $\left.\mathbf{m}^{2}\right)$ \\
\hline RF12y & $298 \pm 278 \mathrm{a}$ \\
RF17y & $77 \pm 96 \mathrm{ab}$ \\
NF & $43 \pm 57 \mathrm{~b}$ \\
AA & $43 \pm 57 \mathrm{~b}$ \\
\hline
\end{tabular}

*Different small letters refer significant difference among study sites (Nemenyi test, $p<0.01, n=4$ )

\subsection{Species similarity of soil seed banks and mature trees}

Species richness of trees of all study sites were 3-8 times higher than their soil seed banks (Figure 3 ). The lowest species richness of trees was found in the abandoned area (Figure 3). In each study site, 5-8 species of soil seed banks were detected (Table 4). Among 14 species of seed banks found in this study, there were only 2-6 species of standing vegetation of the same species presented in each study site. Comparing the proportion of planted trees in the soil seed banks among the restored sites and the abandoned area, 1-3 species of the soil seed banks in RF17y, RF12y, and AA had local plants of the same species (Figure 4).

Similarities between the species found in the soil seed banks and their existing mature trees were compared with Sorensen's similarity index. Among sites, Sorensen's similarities ranged from 0 to $13.79 \%$ (Tables 5 and 6 ). The seed bank species in the 17 -year-old restoration site was more similar to the mature trees in the abandoned area than the other sites. There was no overlapping species found in the seed banks and the trees of NF-RF17y and AA-RF12y (Table 5). Within the site, the highest similarity was found in the 17 -year-old restoration site at $12.77 \%$ while the tree species and soil seed species in NF was totally different. In NF and RF12y, the similarities between the seed banks and the standing vegetation compared to other sites were equal to or larger than those similarities within their sites. Meanwhile, the similarities to other sites varied in both RF17y and AA. 
Soil seed bank aboveground vegetation

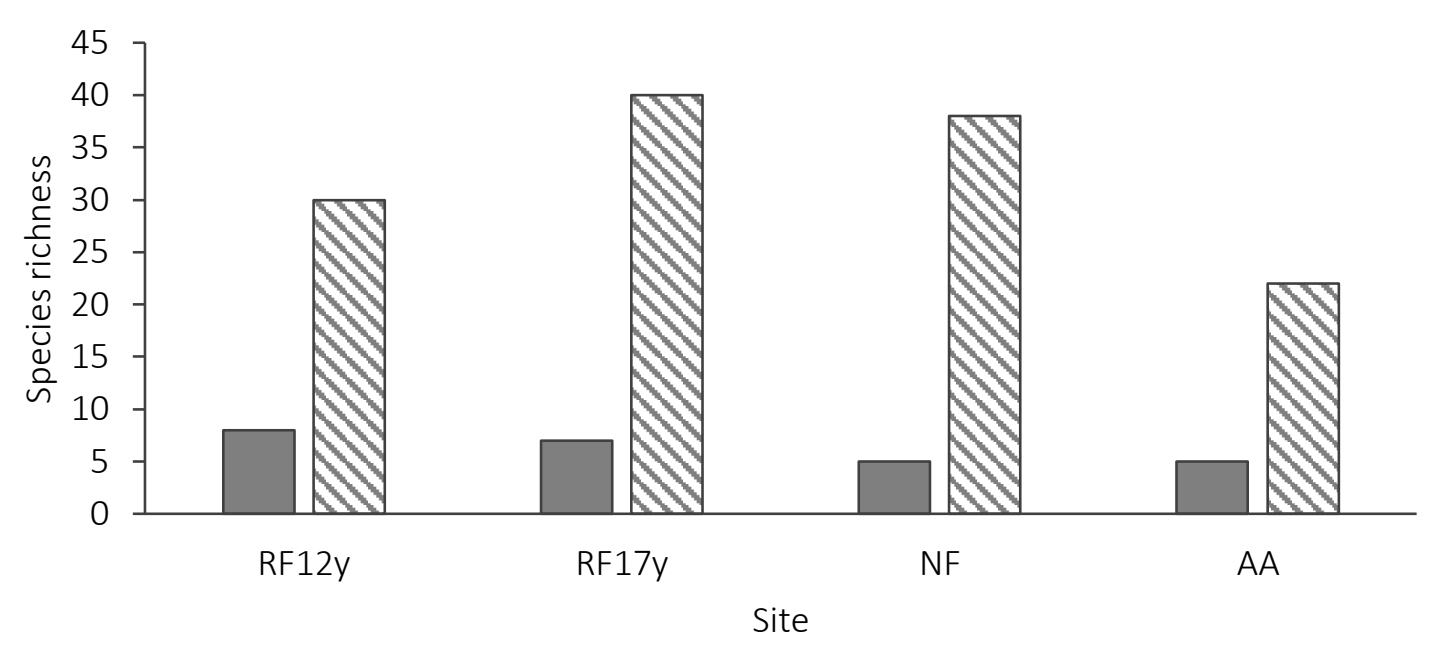

Figure 3. Species richness of soil seed banks and aboveground vegetation in the study sites (RF12y $=12$-year-old restored forest, RF17y $=17$-year-old restored forest, $N F=$ natural forest, $A A$ $=$ abandoned area).

Table 4. Species of trees found in soil seed banks (SB) and their occurrence as mature tree in community $(T)$ in the study sites (RF12y $=12$-year-old restored forest, RF17y $=17$-year-old restored forest, $\mathrm{NF}=$ natural forest, $\mathrm{AA}=$ abandoned area).

\begin{tabular}{|c|c|c|c|c|c|c|c|c|}
\hline \multirow[t]{2}{*}{ Scientific name } & \multicolumn{2}{|c|}{ RF12y } & \multicolumn{2}{|c|}{ RF17y } & \multicolumn{2}{|c|}{ NF } & \multicolumn{2}{|c|}{ AA } \\
\hline & SB & $T$ & SB & $T$ & SB & $T$ & SB & $T$ \\
\hline Albizia chinensis & & & & 1 & & 1 & I & 1 \\
\hline $\begin{array}{l}\text { Archidendron } \\
\text { clypearia }\end{array}$ & / & l & l & l & & I & & / \\
\hline $\begin{array}{l}\text { Artocarpus } \\
\text { lakoocha }\end{array}$ & & l & & & l & & & \\
\hline $\begin{array}{l}\text { Bauhinia } \\
\text { saccocalyx }\end{array}$ & & & & & l & & & \\
\hline $\begin{array}{l}\text { Castanopsis } \\
\text { calathiformis }\end{array}$ & & & / & l & & & & \\
\hline $\begin{array}{l}\text { Cinnamomum } \\
\text { caudatum }\end{array}$ & / & & & & & & & \\
\hline $\begin{array}{l}\text { Debregeasia } \\
\text { longifolia }\end{array}$ & / & & l & & / & & l & \\
\hline Litsea cubeba & / & & I & & & & & \\
\hline $\begin{array}{l}\text { Macaranga } \\
\text { denticulata }\end{array}$ & / & & I & & l & & I & \\
\hline Prunus ceracoides & & l & l & l & & & & \\
\hline $\begin{array}{l}\text { Saurauia } \\
\text { roxberghii }\end{array}$ & & & I & & & & I & \\
\hline Trema orientalis & / & & & & I & & & \\
\hline Turpina pomifera & / & & & I & & I & & \\
\hline $\begin{array}{l}\text { Wendlandia } \\
\text { tinctoria }\end{array}$ & / & & & I & & / & / & \\
\hline Total & 8 & 3 & 7 & 6 & 5 & 4 & 5 & 2 \\
\hline
\end{tabular}




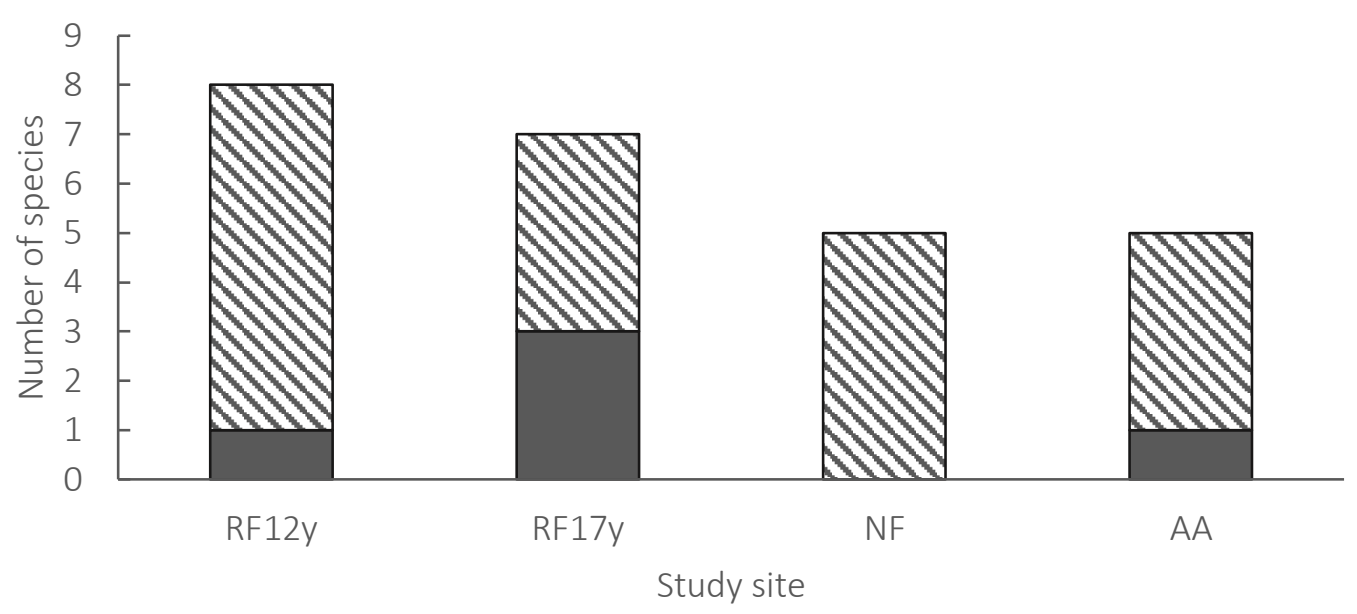

Figure 4. The proportion of planted and non-planted tree species of the soil seed banks in the study sites (RF12y $=12$-year-old restored forest, RF17y $=17$-year-old restored forest, NF $=$ natural forest, $A A=$ abandoned area).

Table 5. Sorensen's similarity index (\%) comparing between species composition in soil seed banks and the tree community within and across the study sites (RF12y $=12$-year-old restored forest, $\mathrm{RF} 17 \mathrm{y}=17$-year-old restored forest, $\mathrm{NF}=$ natural forest, $\mathrm{AA}=$ abandoned area).

\begin{tabular}{ccccc}
\hline & \multicolumn{4}{l}{ \% Similarity between sites } \\
\hline $\begin{array}{c}\text { Seed bank } \\
\text { Vegetation }\end{array}$ & RF12y & RF17y & NF & AA \\
\hline RF12y & 5.26 & 10.81 & 5.71 & 0.00 \\
RF17y & 12.50 & 12.77 & 0.00 & 8.89 \\
NF & 13.04 & 4.44 & 0.00 & 9.30 \\
AA & 6.67 & 13.79 & 7.41 & 7.41 \\
\hline
\end{tabular}

Table 6. List of tree species $(\mathrm{dbh} \geq 2.5 \mathrm{~cm}$ ) from the tree survey of four study sites (RF12y $=12$-yearold restored forest, RF17y $=17$-year-old restored forest, $N F=$ natural forest, $A A=$ abandoned area).

\begin{tabular}{llll}
\hline \multirow{2}{*}{ Scientific name } & Family & \multicolumn{2}{c}{ Study site } \\
\cline { 2 - 4 } Alangium kurzii Craib & RF12y & RF17y & NF \\
Albizia chinensis (Osbeck) Merr. & Alangiaceae & $/$ & $/$ \\
Albizia odoratissima (L. f.) Benth. & $\begin{array}{l}\text { Leguminosae } \\
\text { (Mimosoideae) }\end{array}$ & $/$ \\
Alseodaphne andersonii (King ex Hook.f.) Kosterm. & Leguminosae \\
Antidesma bunius (L.) Spreng & Lauraceae & $/$ \\
Aporosa wallichii Hook.f. & Euphorbiaceae & $/$ & $/$ \\
Archidendron clypearia (Jack) I.C.Nielsen & Euphorbiaceae & $/$ & $/$ \\
Artocarpus lacucha Buch.-Ham. & Leguminosae & $/$ & $/$ \\
\hline
\end{tabular}




\begin{tabular}{|c|c|c|c|c|c|}
\hline \multirow{2}{*}{ Scientific name } & \multirow{2}{*}{ Family } & \multicolumn{4}{|c|}{ Study site } \\
\hline & & RF12y & RF17y & NF & AA \\
\hline Artocarpus nitidus Trécul & Moraceae & / & & / & \\
\hline Baccaurea ramiflora Lour. & Euphorbiaceae & & & / & \\
\hline Beilschmiedia intermedia C.K. Allen & Lauraceae & / & / & & \\
\hline Berrya mollis Wall. ex Kurz & Tiliaceae & & / & / & \\
\hline Bischofia javanica Blume & Euphorbiaceae & / & & & \\
\hline Bombax ceiba $\mathrm{L}$. & Bombacaceae & / & & & \\
\hline Bridelia glauca Blume & Euphorbiaceae & / & & & \\
\hline Callicarpa arborea Roxb. & Verbenaceae & & & / & \\
\hline Canarium subulatum Guillaumin & Burseraceae & & & / & \\
\hline Castanopsis acuminatissima (Blume) A. DC. & Fagaceae & & / & / & \\
\hline $\begin{array}{l}\text { Castanopsis calathiformis (Skan) Rehder and } \\
\text { E.H.Wilson }\end{array}$ & Fagaceae & & / & & \\
\hline Castanopsis diversifolia (Kurz) King ex Hook.f. & Fagaceae & & / & / & \\
\hline Castanopsis tribuloides (Sm.) A. DC. & Fagaceae & & & / & \\
\hline $\begin{array}{l}\text { Choerospondias axillaris (Roxb.) B.L.Burtt and } \\
\text { A.W.Hill }\end{array}$ & Anacardiaceae & / & / & & / \\
\hline Cinnamomum iners Reinw. ex Blume & Lauraceae & & / & & \\
\hline Dalbergia oliveri Prain. & $\begin{array}{l}\text { Leguminosae } \\
\text { (Papilionoideae) }\end{array}$ & / & & / & \\
\hline Dalbergia ovata Benth. & $\begin{array}{l}\text { Leguminosae } \\
\text { (Papilionoideae) }\end{array}$ & / & / & & / \\
\hline Dillenia parviflora Griff. & Dilleniaceae & & & & / \\
\hline Diospyros glandulosa Lace & Ebenaceae & & / & & \\
\hline Elaeocarpus lanceifolius Roxb. & Elaeocarpaceae & & / & & / \\
\hline $\begin{array}{l}\text { Engelhardia spicata var. colebrookeana (Lindl. ex } \\
\text { Wall.) Koord. and Valeton }\end{array}$ & Juglandaceae & & & / & \\
\hline Erythrina subumbrans (Hassk.) Merr. & $\begin{array}{l}\text { Leguminosae } \\
\text { (Papilionoideae) }\end{array}$ & & / & & \\
\hline Eucalyptus sp. & Myrtaceae & / & & & \\
\hline $\begin{array}{l}\text { Eugenia albiflora (Duthie ex Kurz) Bahadur and } \\
\text { R.C.Gaur }\end{array}$ & Myrtaceae & & & / & \\
\hline Eurya acuminata DC. & Theaceae & & & / & \\
\hline Ficus altissima Blume & Moraceae & & / & & \\
\hline Garcinia mckeaniana Craib & Guttiferae & & / & & \\
\hline Glochidion acuminatum Müll.Arg. & Euphorbiaceae & & & / & \\
\hline Glochidion kerrii Craib & Euphorbiaceae & & & / & \\
\hline Glochidion sphaerogynum (Müll.Arg.) Kurz & Euphorbiaceae & / & / & / & / \\
\hline Gluta obovata Craib & Anacardiaceae & & & / & \\
\hline Gmelina arborea Roxb. & Verbenaceae & & & & / \\
\hline Helicia nilagirica Bedd. & Proteaceae & & / & & \\
\hline Heynea trijuga Roxb. ex Sims & Meliaceae & & / & & \\
\hline Hovenia dulcis Thunb. & Rhamnaceae & / & & & \\
\hline Ilex umbellulata (Wall.) Loes. & Aquifoliaceae & & / & / & \\
\hline $\begin{array}{l}\text { Lithocarpus elegans (Blume) Hatus. ex Soep. } \\
\text { Soepadmo }\end{array}$ & Fagaceae & & & / & \\
\hline Lithocarpus garrettianus (Craib) A.Camus & Fagaceae & & / & & / \\
\hline
\end{tabular}




\begin{tabular}{|c|c|c|c|c|c|}
\hline \multirow{2}{*}{ Scientific name } & \multirow{2}{*}{ Family } & \multicolumn{4}{|c|}{ Study site } \\
\hline & & RF12y & RF17y & NF & AA \\
\hline Lithocarpus polystachtus (Wall. ex A.DC.) Rehder & Fagaceae & & & / & \\
\hline Litsea cubeba (Lour.) Pers. & Lauraceae & & & & / \\
\hline Litsea glutinosa (Lour.) C.B. Rob. & Lauraceae & / & & / & \\
\hline Litsea salicifolia (J. Roxb. Ex Nees) Hook.f. & Lauraceae & / & / & / & \\
\hline Machilus gamblei King ex Hook. f. & Lauraceae & / & / & / & / \\
\hline Magnolia baillonii Pierre & Magnoliaceae & & & / & / \\
\hline Magnolia garrettii Craib V.S.Kumar & Magnoliaceae & & / & & \\
\hline Magnolia floribunda (Finet and Gagnep.) Figlar & Magnoliaceae & / & & & \\
\hline Mallotus philippensis (Lam.) Müll.Arg. & Euphorbiaceae & / & & & \\
\hline Markhamia stipulata (Wall.) Seem. & Bignoniaceae & / & / & & / \\
\hline Nyssa javanica (Blume) Wang. & Nyssaceae & & / & & \\
\hline Ocotea lancifolia (Schott) Mez & Lauraceae & & & / & \\
\hline Oroxylum indicum (L.) Kurz & Bignoniaceae & & & & / \\
\hline Phyllanthus emblica $\mathrm{L}$. & Euphorbiaceae & / & / & & / \\
\hline Pinus kesiya Royle ex Gordon & Pinaceae & & & & / \\
\hline Prunus cerasoides Buch.-Ham. ex D. Don & Rosaceae & / & / & & / \\
\hline Quercus semiserrata Roxb. & Fagaceae & & / & & \\
\hline Sapindus rarak DC. & Sapindaceae & / & / & & \\
\hline Sarcosperma arboreum Hook.f. & Sapotaceae & / & / & / & \\
\hline Schima wallichii Choisy & Theaceae & & / & / & / \\
\hline Scleropyrum pentandrum (Dennst.) Mabb. & Santalaceae & & & / & \\
\hline Semecarpus cochinchinensis Engl. & Anacardiaceae & & & / & \\
\hline Sterculia villosa Roxb. & Sterculiaceae & / & / & / & / \\
\hline Styrax benzoides W. G. Craib & Styracaceae & / & / & & \\
\hline Symplocos racemosa Roxb. & Symplocaceae & & & / & \\
\hline $\begin{array}{l}\text { Syzygium claviflorum (Roxb.) Wall. ex A.M.Cowan } \\
\text { and Cowan }\end{array}$ & Myrtaceae & & / & / & / \\
\hline Toxicodendron rhetsoides (W. G. Craib) Tardieu & Anacardiaceae & & & & / \\
\hline Turpinia pomifera (Roxb.) DC. & Staphyleaceae & & / & / & \\
\hline Vitex quinata (Lour.) F.N.Williams & Verbenaceae & / & & & \\
\hline Wendlandia tinctoria (Roxb.) DC. & Rubiaceae & & / & / & \\
\hline Xantolis burmanica (Collett and Hemsl.) P. Royen & Sapotaceae & & / & & \\
\hline unknown species1 & & / & & & \\
\hline unknown species2 & & / & / & & \\
\hline
\end{tabular}

\subsection{How does forest restoration age affect seed deposition in soils?}

In this study, the ages of forest restoration (12-year-old and 17-year-old) did not significantly affect seed densities. Mean seed densities of both restored forests were greater than NF and AA, but only the density of RF12y was significantly different from those sites (42-297 seeds/ $\mathrm{m}^{2}$ ). In addition, species richness of the tree seed banks seemed to decrease in the older sites and the natural forest. Fewer seed densities in the older restoration site may be due to fewer pioneer species in the older restoration site. In the younger restoration site (RF12y), there were more pioneer trees e.g. Debregeasia longifolia and Wendlandia tinctoria containing numerous tiny seeds, 
which easily entered the soil seed banks. Another possible reason of lower density in the older restoration site is that environmental conditions may promote seed germination. Fast germination is a characteristic of some tree seeds in tropical regions (Garwood, 1989).

Previous studies have shown that different restoration approaches and age after restoration affected soil seed densities and species richness (Chen et al., 2013; González-Rivas et al., 2009; Martins and Engel, 2007; Miao et al., 2016). In agriculture fields in Nicaragua with 0-year-old, 4-yearold, and 9-year-old abandonment, seed densities decreased in longer abandoned periods. However, species richness of plants increases in older abandonment, and few woody species (0-3 species) are found in those soil seed banks (González-Rivas et al., 2009). Another experiment of passive restoration in Mongolia for 0-12 years reveals that the older restoration sites have higher species richness (Miao et al., 2016). The seed densities including non-tree seeds of those studies rise in the longer treatment periods, which differ from the current study of tree seeds. Nevertheless, the seed densities in this study were comparable to previous study of Castanopsis and dry dipterocarp forests in Chiang Mai (137-243 seeds/ $\mathrm{m}^{2}$ ) (Cheke et al., 1979). Furthermore, the study of viable seeds in Xishuangbana, SW China support our result in which the seed densities in the younger secondary forests were higher than those found in both the older ones and the climax forest (Cao et al., 2000). The restoration approach affects seed density and species richness in soil seed banks, but the effects are specific to the sites and ecosystems.

\subsection{How does the framework species method engage species composition in the soil seed banks?}

In the current study, forest restoration helps to increase seed dispersal by attracting animals to the areas and assists in increasing natural regeneration of the area. In the restored forests, the majority of seeds in the soil seed banks were of animal dispersal species. Eight out of 14 species of soil seed banks had no mature mother tree in the sites. Seven out of the eight species (87.5\%) in the soil seed bank of restored sites were animal dispersed. This suggested that those seven species' seeds were brought to the restored sites by animals. In contrast, in the abandoned area, three out of five seed species (60\%) were dispersed by animals. In addition, the proportion of planted species found in the seed bank of the restored forests was greater than that of the abandoned area. This result suggested that the framework species increased natural regeneration more than the natural process. It is worth noting that seed dispersal from the natural forest was still limited due to long distances of several kilometers from the natural forest. The nearest distance from the natural forest to the restored forest at Ban Mae Sa Mai was over $1.3 \mathrm{~km}$. Macaranga denticulata and Trema orientalis, pioneer trees, had previously showed $175 \mathrm{~m}$ dispersal distance from their sources (Cheke et al., 1979).

Similarities between soil seed banks and standing mature trees within the same site and between the sites indicated seed dispersal and/or seed rain from framework tree species. The similarity within the same site of RF17y as being $12.77 \%$ showed that some seeds in the restoration site dispersed from existing species while that in the similarity of the natural forest, equaled $0 \%$, suggesting all species in the seed banks came from non-local dispersal. Those similarities within the same site of RF12y and AA ( $<10 \%)$ were comparable, but they displayed less local dispersal than that of RF17y. Similarly, tropical forests in Ghana and Mexico have $0-20 \%$ similarities between soil seed banks and living vegetation. The same article reported that the seed banks exhibit larger similarities to the standing vegetation between studied areas than at the local sites (Garwood, 1989). The similarities across sites between the seed banks and the vegetation of AA was comparable to those of NF $(<10 \%)$, but they were smaller than those of the restoration sites, on average. In restoration sites, species of the seed banks in RF12y had greater similarity to trees of neighboring sites ( $>6 \%$ ) than those of itself. Meanwhile, the similarities to other sites of seed banks in RF17y were $>10 \%$ except for NF (4\%). In AA, the seed bank species were as similar to the vegetation in NF and RF17y as within the areas. These results implied that AA may provide higher opportunity of seed dispersal 
across the sites due to standing trees. All of the overlapping between soil seed bank and tree species were framework tree species. Owing to special characteristics of framework tree species to produce a lot of seeds and to influence animal dispersal (Elliott et al., 2003), most of the seed banks found in this research may come from the restored forests. This result was also supported by several studies that indicated similarity among soil seed banks and standing vegetation, which might either have no overlap or has a poor to medium relationship (González-Rivas et al., 2009; Kostel-Hughes et al., 1998; Li et al., 2007; Lipoma et al., 2018; Wang et al., 2013).

The framework tree species contributed to accumulation of soil seed banks by increasing seed dispersal by animals and seed rains. After 12 and 17 years of restoration, there were 5-8 tree species in the soil seed bank of the restoration sites and adjacent abandoned areas. In Nicaragua, it took 14 years to gain three species of tree seed banks in abandoned sites (González-Rivas et al., 2009). Even passive restoration accelerates species richness of soil seed banks in the first few years, although it was still slower than the active ones and also contained fewer woody species (Miao et al., 2016). Seed dispersers and dispersal distance were suggested for further evaluation.

\section{Conclusions}

The seed density and the species composition of the soil seed banks varied among sites. The ages of forest restoration did not directly affect the seed densities, but the standing vegetation and dispersal mechanism affected the presence of species in the soil seed banks. Our study found that the seed densities and species richness were lower in the older restored site. The species similarities between the soil seed banks and the standing vegetation at the same site were comparable to previous studies. The similarities of the seed banks and the vegetation of neighboring sites suggested seed movement among sites by dispersal. Most of the species found in the soil seed banks were animal-dispersed species. The finding suggested that planting framework species trees in the areas helps to attract animal seed dispersers. This research provides evidence of the advantages of active forest restoration by the framework species method. Further studies are needed on dispersal distance and seed dispersers for species used in restoration. Moreover, forest practitioners should pay attention to the proportion of animal-dispersed species when selecting target species for restoration.

Author Contributions: P.R. and S.C. designed the research; P.R. performed the experiment; P.R., S.C. and P.T. analyzed the data; S.C., A.J. and D.S. contributed materials and analysis tools; P.R., P.T. and S.C. wrote and edited the manuscript; All authors discussed the results and commented on the manuscript.

Conflicts of Interest: The authors declare no conflict of interest.

Acknowledgments: The first author is grateful for a study scholarship from the Human Resource Development in Science Project (Science Achievement Scholarship of Thailand, SAST) and benefited from a graduate research scholarship from the Graduate School of Chiang Mai University. We would like to thank all Forest Restoration Research Unit (FORRU) staff for their support in field research, plant identification, and nursery work. We would also like to gratefully thank the village headman of Ban Mae Sa Mai Village for the permission of sample collection around Mae Sa Valley. This study was partly supported by the Center of Excellence on Biodiversity (BDC-PG3-160019).

\section{References}

Blakesley, D., Elliott, S., Kuarak, C., Navakitbumrung, P., Zangkum, S., \& Anusarnsunthorn, V. (2002). Propagating framework tree species to restore seasonally dry tropical forest: implications of seasonal seed dispersal and dormancy. Forest Ecology and Management, 164(1-3), 31-38. https://doi.org/10.1016/S0378-1127(01)00609-0 
Cao, M., Tang, Y., Sheng, C., \& Zhang, J. (2000). Viable seeds buried in the tropical forest soils of Xishuangbanna, SW China. Seed Science Research, 10(3), 255-264. https://doi.org/10.1017/S0960258500000283

Cheke, A. S., Nanakorn, W., \& Yankoses, C. (1979). Dormancy and Dispersal of Seeds of Secondary Forest Species Under the Canopy of a Primary Tropical Rain Forest in Northern Thailand. Biotropica, 11(2), 88-95. https://doi.org/10.2307/2387783

Chen, H., Cao, M., \& Tang, Y. (2013). Soil seed banks in plantation and tropical seasonal rainforests of Xishuangbanna, south-west China. Journal of Tropical Forest Science, 25(3), 375-386. Retrieved April 24, 2021, from http://www.jstor.org/stable/23617239

dos Santos, D. M., da Silva, K. A., de Albuquerque, U. P., dos Santos, J. M. F. F., Lopes, C. G. R., \& Araújo, E. d. L. (2013). Can spatial variation and inter-annual variation in precipitation explain the seed density and species richness of the germinable soil seed bank in a tropical dry forest in north-eastern Brazil? Flora - Morphology, Distribution, Functional Ecology of Plants, 208(7), 445-452. http://dx.doi.org/10.1016/j.flora.2013.07.006

Elliott, S., Navakitbumrung, P., Kuarak, C., Zangkum, S., Anusarnsunthorn, V., \& Blakesley, D. (2003). Selecting framework tree species for restoring seasonally dry tropical forests in northern Thailand based on field performance. Forest Ecology and Management, 184(1-3), 177-191. http://dx.doi.org/10.1016/S0378-1127(03)00211-1

Forest Restoration Research Unit, Chiang Mai University (FORRU-CMU) (2014) FORRU database.

Garwood, N. (1989). Tropical Soil Seed Banks: A Review. In (pp. 149-209). https://doi.org/10.1016/B978-0-12-440405-2.50014-2

González-Rivas, B., Tigabu, M., Castro-Marín, G., \& Odén, P. (2009). Soil seed bank assembly following secondary succession on abandoned agricultural fields in Nicaragua. Journal of Forestry Research, 20(4), 349-354. https://doi.org/10.1007/s11676-009-0059-2

Kostel-Hughes, F., Young, T., \& McDonnell, M. (1998). The soil seed bank and its relationship to the aboveground vegetation in deciduous forests in New York City. Urban Ecosystems, 2(1), 43-59. https://doi.org/10.1023/A:1009541213518

Li, N., Feng, G., \& Tian, C. (2007). Characteristics and dynamics of the soil seed bank at the north edge of Taklimakan Desert. Science in China Series D: Earth Sciences, 50(1), 122-127. https://doi.org/10.1007/s11430-007-5005-6

Lipoma, M. L., Funes, G., \& Díaz, S. (2018). Fire effects on the soil seed bank and post-fire resilience of a semi-arid shrubland in central Argentina. Austral Ecology, 43(1), 46-55. https://doi.org/doi:10.1111/aec.12533

Ludwig, J. A., \& Reynolds, J. F. (1988). Statistical Ecology: A Primer on Methods and Computing. Wiley.

Martins, A. M., \& Engel, V. L. (2007). Soil seed banks in tropical forest fragments with different disturbance histories in southeastern Brazil. Ecological Engineering, 31(3), 165-174. http://dx.doi.org/10.1016/j.ecoleng.2007.05.008

Maxwell, J. F., \& Elliott, S. (2001). Vegetation and Vascular Flora of Doi Sutep-Pui National Park, Chiang Mai Province, Thailand. Thai Studies in Biodiversity 5. Biodiversity Research \& Training Programme, Bangkok. 205 pp.

Miao, R., Song, Y., Sun, Z., Guo, M., Zhou, Z., \& Liu, Y. (2016). Soil Seed Bank and Plant Community Development in Passive Restoration of Degraded Sandy Grasslands. Sustainability, 8(6), 581. https://doi.org/10.3390/su8060581

Pohlert, T. (2014). The Pairwise Multiple Comparison of Mean Ranks Package (PMCMR). In R package. http://CRAN.R-project.org/package=PMCMR

R Core Team. (2016). R: A language and environment for statistical computing. In (Version 3.3.1) R Foundation for Statistical Computing, Vienna, Austria. https://www.R-project.org/

Royal Project Thailand (Mae Sa Mai Station) (2016) Climate_Maesa 
Sorensen, T. (1948). A Method of Establishing Groups of Equal Amplitude in Plant Sociology Based on Similarity of Species Content. Kobenhavn.

Upper Northern Region Irrigation Hydrology Center (2020). Rainfall data, Thailand. https://www.hydro-1.net/main/3-RAIN.php

Vázquez-Yanes, C., \& Orozco-Segovia, A. (1996). Physiological ecology of seed dormancy and longevity. In Tropical forest plant ecophysiology (pp. 535-558). Springer, Boston, MA.

Wang, Y., Jiang, D., Toshio, O., \& Zhou, Q. (2013). Recent advances in soil seed bank research. $\begin{array}{llll}\text { Contemporary Problems of 520logy, 6(5), } & \text { 524. }\end{array}$ https://doi.org/10.1134/S1995425513050181 